瓷料

\title{
鉛,覀鉛の純度とその性 質*
}

\author{
徳永惊 \\ （三井金風鉱業株式会社東京研究所）
}

\section{1. 芧言}

金属は人類の生活に取つて欠くべからざる材料であっ て有史以前加人類交化の発展伴つて益々先の重要性 を增してきた・殊に前世紀加ら今世紀啮つて急激に発 達した科学, 技術は各種の金属とその合金の力保うと ころが大であつたが, 現在に於ては今まで以上に新しい 金属とその合金が研究及びその工業化のため㴗求され ている.

科学技術者の求めている金属及び合金の性暂恃研究の 発展と共に益々複雑となり，金属材料の研究者及び生産 者はこれらの要求を充すため限られた金属元素とそれ らの組合せ飞よる合金の物理的，化学的性質を研究し繶 けている。

金属元素の性質以昔から多数の科学者飞よつて研究さ れ，数多く参考書記載されているがその性質をあらわ す数值は研究者の年代炕よつて異つて括り, 研究化使わ れた金属の純度によつて甚しい差異がある。

換言す机ば真純䊀な金属元素は目のあたり見ること は出来ないのであつて、我々が日常「純粋金属」として

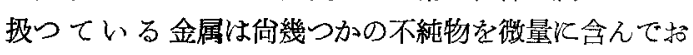
り，この微量の不維物の種類や多少炕よつて金属の物理 的, 化学的性質が異る事契が認められる.

又合金の性筫にしてもこれの成分である金属元素の綝 度にようて甚しい差異があるのでこれる工業的浰用す る場合には特澺を用いなければならない。

金属のハンドブック記載されている合金の状態図も 成分である金属の純度が上昇する伴つて訂正されて行 くのはこれをよく物語つている。

最近《和ける科学の発達ね益々高純度の金属及び合金 を必要とし，金属の価格も純度によつて差があるので製 錬業者は需要がある限り生産する金属の純度を上げるこ とに苦心してドる. 銅, 鉛, 两鉛, ニッケル,アルミニ ウム、マグネシウム等の純度が年と共に高くなり，これ らの金属から造つた合金も今までない優秀な性能を示 すに至つたととけ影著な事実であり，そのためにこれら の金属と合金の需要範围が桩大されてきている。

金属の純度の差異が如何にその金属及びその合金の性

\footnotetext{
* 旺和 31 年 2 月 24 日䉓気化学協会関東支部「高純度金属沪関与\% 绕演会に於て講演
}

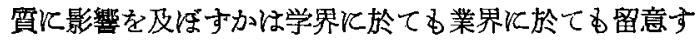
ベきととであるので鈶と亜鉛の純度とその性筫について 述べて見たい.

\section{2. 鉛の純度とその性質}

\section{1. 鉿の精製}

金属鉛の主原料方鉛鉱 $(\mathrm{PbS})$ であつて，この精鉱を 酸化焙烧して酸化鉛となし，これにコークス，鉄序，熔 剂を加えて熔鉱焒で還元し，粗鉛を造り，これを電解精 製して純度の高い霞気鉛にする。この際 $\mathrm{Pb}, \mathrm{Sn}, \mathrm{Zn}, \mathrm{Fe}$ ， $\mathrm{Ni}, \mathrm{Co}$ 等は電解液㹸入り, $\mathrm{Cu}, \mathrm{Sb}, \mathrm{As}, \mathrm{Bi}, \mathrm{Cd}, \mathrm{Ag}, \mathrm{Au}$, $\mathrm{Se}, \mathrm{Te}$ 等は陽極使留与るかスライムとして電槽の底 に沈む ${ }^{(1)}$. 前者の内 $\mathrm{Sn}$ ほ $\mathrm{Pb}$ と電位が似ているので $\mathrm{Pb}$ と共に陰極に析出し易く, 又後者の内 $\mathrm{Sb}$ 注電解電流密 度が高い場合には幾分陰極に入るととがあるのでSn と $\mathrm{Sb}$ は粗鉛の乾式精製の時除き，更に陰極鉛のポーリ ングによつて除くことが必要である。

粗鉛中の不純物の種類と量认電着鉛の純度々密接な関 係がある.一般の場合粗銛の不純物は総量 $2 \sim 3 \%$ 程度 以下でその内 $\mathrm{Sb}$ が過半量を占める. 粗鉛陽極の中不純 物が少い程陰極に電着する鉊の品位が高くなるというこ とはなく，一定の電解条件に於て最高純度の電気鉛を得 るためと必要な粗鉛中の不純物の種類とその量の範囲が むることが明らかてされた文粗鉛を陽極として電解す る場合，陽極の面汇残るスライムが容星沉極面から離れ 落ちないような，しかすをの組織が海綿のようと多孔質 である場合には必ず電着鉿の品位は高い，即らこの場合 はスライムを構成する $\mathrm{Cu}, \mathrm{Sb}, \mathrm{As}, \mathrm{Bi}, \mathrm{Cd}$ 等が粗鉛陽極 との電気鉛に相接しているのでこれらの電気化学的に貴 なる金属群は鉛炕ってイオン化或は酸化を妨げられ る.そして鉛イオンはこれらの金属から成る多孔筫の居 去容易に通り抜けて陰極電着する・スライムの風が多 孔質でなく堅固なるのである場合愖价しい陽極分極に 上つて不純物は容易にイオン化して液中に入り, 更に陰

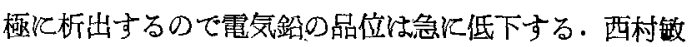
雄 ${ }^{(3)}$ は粗鈶中の As, $\mathrm{Sb}, \mathrm{Bi} の 3$ 元素の含有量を調整す ることによつて Pb 99.99+\% の高純度鉊の電着老確保 乙得ることを実証した。乙の場合の As, Sb，Bi の合有率 は次の範囲であつた。

As $0.4 \sim 1.3 \%$ Sb $0.3 \sim 0.95 \%$ Bi $0.5 \sim 0.8 \%$ 
粗鉛をハリス法文はパークス法で或程度精製して電解 精製にかける場合でる上に述べた理由によりとの乾式精 製の限度を過せば却つて電気鉛の品位が下ることに注意

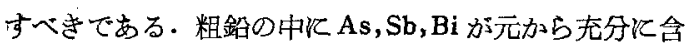
まれていない場合にはむしるこれらの金属を合む故鉛を 添加して調節した方が高純度の電気鉛を得る場合もむ る.

鉛の電解精製に於ては，粗鉛陽極の表面に残るスライ ムは漱次厚さを増し，その組織肪多孔質であつても鉛イ オンの移動の障害となり，陽極の分極も大きくなるので 4〜6 日毎に壆極を引揚げてスライムを剝ぎ落さねば電 着する鉛の高品位を保つことが出来ない。

\section{2. 湢笑鉛の品位}

従来の鉛電解工場で生産される電気鉛は 99.98〜99.99 安の品位であつたが最近は更に高純度の 99.995 99.998 96 程度の電気鉛が生産されるに至つた。第 1 表は代表的 高純度鉛の成分を示したるのである。

第 1 表 高純度電気鉛の分析表（\%)

\begin{tabular}{|c|c|c|c|c|}
\hline 成 分 & $\underset{\text { (加奈陀) }}{\text { TADAC }}$ & (独 $\mathbf{N A}^{\mathbf{*}}$ 逸) & $\begin{array}{l}\text { 神 岡(1) } \\
\left(\begin{array}{ll}\text { 本 } \\
\text { (1) }\end{array}\right)\end{array}$ & $\begin{array}{l}\text { 神 咸(2) } \\
(\text { 至 }\end{array}$ \\
\hline $\mathrm{Cu}$ & 0.0002 & 0.0002 & 0.0011 & 0.0009 \\
\hline $\mathbf{B i}$ & 0.0002 & 0.0015 & 0.0002 & 0.0027 \\
\hline As & 0.0002 & - & trace & trace \\
\hline $\mathbf{S b}$ & 0.0020 & 0.0002 & 0.0006 & 0.0007 \\
\hline $\mathrm{Ni}+\mathrm{Co}$ & - & - & trace & - \\
\hline $\mathrm{Fe}$ & 0.0015 & 0.0005 & 0.0013 & 0,0005 \\
\hline $\mathrm{Cd}$ & - & trace & - & $\longrightarrow$ \\
\hline $\mathrm{Zn}$ & 0.0007 & trace & 0.0007 & 0.0007 \\
\hline Ag & 0.0007 & 0.00005 & 0.0001 & 0.0006 \\
\hline $\mathrm{Au}$ & 0.000003 & 0.000001 & - & - \\
\hline P. $\mathbf{b}$ & 99.9950 & 99.9975 & 99.9960 & 99.994 \\
\hline
\end{tabular}

以上のような高純度錴は工業的に大量に生産されてい るすのであつて製錬業者が競つて製品の純度の上舁に努 力しているのは需要者が鉛を入手する昜合に出来るだけ 高品位を求めるからである.99.995\%或はそれ以上の品

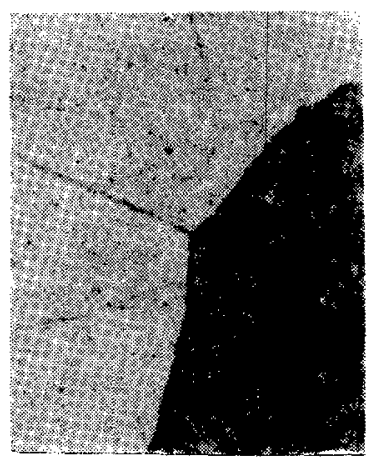

第 1 因

高純度鉛 $(99.995 \% \mathrm{~Pb})$ ，金型鋳造後 $200^{\circ} \mathrm{C}$, $5 \mathrm{~h}$ 焼鈍試料の顕微鏡組織 $\left(\mathrm{H}_{2} \mathrm{O}_{2}+\mathrm{CH}_{3} \mathrm{COOH}\right)$ エツテ $\times 400$
位を持つた高純度鉛はそのま〉で使用される場合よりる $\mathrm{Sn}, \mathrm{Sb}, \mathrm{Cu}, \mathrm{Ag}$ その他を加えて使用されるととが多いの であるがこの場合でる鉛の機械的性賈や耐蝕性を悪くし ないためには出来るだけ高純度の鉛を基調としなければ ならない，第1図は 99.995\% の高純度鉊の顕微鏡組織 を示す，更にこれ以上の品位の鉊は工業的必要としな いが学術研究や特殊の用途には必要である。例えば鉛の 単結晶の物理学的研究や鉛の物理的, 化学的性䁚に対す る㪍量不純物の影響に関する研究等には 99.999+\%の 超高純度鉛が必要である.Cowan(4) はこの目的のために $99.999+\%$ の電気鉛をパークス法で脱銀し，これる再電 解して次の品位の電気鉛を得た。

\begin{tabular}{|c|c|c|c|c|c|c|}
\hline $\mathrm{Ag}$ & $\mathrm{Sb}$ & $\mathrm{Cu}$ & $\mathrm{Fe}$ & $z_{n}$ & $\mathrm{Bi}, \mathrm{Sn}, \mathrm{As}, \mathrm{P}$ & Pb. \\
\hline な2 & 0.000 & 00005 & 0.000193 & 0.00008 & trace & 99.99943 \\
\hline
\end{tabular}

この製品を分析するには試料 $1000 \mathrm{~g}$ を採らねな゙なら なかつた。

\section{3. 豪純度釭の物理的性啠}

金虽鉛の物理的性兵の主なるるのを次に挙げる。

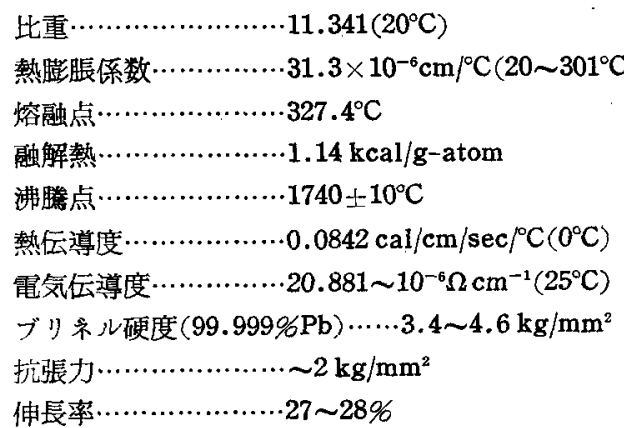

後に述べる如く鉛は最純のるのが硫酸ての他に対して 最も酎強が強いが99.99\% 99.997\%純度の鉛は抗張力， 王縮強度が弱く，硬度る低いためむしろ耐蝕性を多少儀 牲化しても $\mathrm{Ag}-\mathrm{Ca}, \mathrm{Cu}$ 等を少量入れるか $\mathrm{Sb}$ を数\%入 れて合金した上で構造材料に使用する方が経済的である 場合が少くない。

㕛最純鉛は $60 \sim 80^{\circ} \mathrm{C}$ で勿論常温に於てる徐々に再 結晶や結鼠の成長を起し, 又クリープ現象る起るので硫 酸工場や化学工場で高純度銛を用いるときは特に注意す る必要がある。

鉊を鉛板，鉛管その他の構造材料として用いるときは その用途に応じて鉛地金の材筫を選ぶ必要があるがその 用途が鉛の耐蝕性之機械的強度を同時偠求する場合が 多く，しか子や小高温度に於て用いる場合が多いので最 高純度の鉛をそのま」用い得ない場合が多い，第 2 図は $99.9 \%$ 以上の純度の鉛上それに $\mathrm{Ca}, \mathrm{Cu}, \mathrm{Mg}, \mathrm{Ag}, \mathrm{Bi}, \mathrm{Sb}$ をそれそれ 0.1\%深加した合金のクリープKよる伸びと 時間との関係を示す曲線である(5).この図が示すように 純度 $99.9 \%$ 鉛に $\mathrm{Ca}, \mathrm{Cu}, \mathrm{Mg}$ のいずれかを僅かに0.19\% 
第 2 表 鉛ケーブルジース合金のクリープ試験結果(6)

\begin{tabular}{|c|c|c|c|c|c|c|c|c|}
\hline \multirow{3}{*}{ 材 } & \multirow{3}{*}{ 形 } & \multirow{3}{*}{\multicolumn{2}{|c|}{ 状 }} & \multirow{3}{*}{$\begin{array}{c}\text { 秸 昆粒子り } \\
\text { 平 均 面 積 } \\
\left(\mathbf{m m}^{2}\right)\end{array}$} & \multicolumn{2}{|c|}{ 荷 } & \multicolumn{2}{|c|}{ 重 } \\
\hline & & & & & \multicolumn{2}{|c|}{$21 \mathrm{~kg} / \mathrm{cm}^{2}$} & \multicolumn{2}{|c|}{$70.5 \mathrm{~kg} / \mathrm{cm}^{2}$} \\
\hline & & & & & $\begin{array}{c}\text { 平衡クリープ } \\
\text { 度 }\end{array}$ & 破壊 迄 & $\begin{array}{c}\text { 平衛クリープ } \\
\text { 速 }\end{array}$ & $\begin{array}{c}\text { 破侍 } \\
\text { 間 }\end{array}$ \\
\hline TADANAC & 伿 & $1=$ & ブ & 0.33 & $1.3 \times 10^{-6}$ & $18,000^{*}$ & - & $24 \sim 26$ \\
\hline $\begin{array}{l}\text { B.S. } 1085 \\
\text { Ag } 0.005, \text { Cu } 0.005\end{array}$ & バ & $1=$ & T゙ & 0.17 & $3.0 \times 10^{-7}$ & $18,000^{*}$ & $2.8 \sim 3.0 \times 10^{-4}$ & $520 \sim 580$ \\
\hline $\begin{array}{ll}\mathrm{Cu} & 0.06 \% \\
\text { 合 } & \text { 金 }\end{array}$ & パ & $1=$ & プ & $0.005 \sim 0.01$ & $5.3 \times 10^{-6}$ & $18,000^{*}$ & $1.3 \sim 2.2 \times 10^{-3}$ & $110 \sim 120$ \\
\hline $\begin{array}{l}\text { Ag } 1 \% \\
\text { 合 金 }\end{array}$ & ハ & $1=$ & $\mathscr{T}$ & 0.0003 & $8.6 \times 10^{-8}$ & $15,000^{*}$ & $2.4 \times 10^{-5}$ & 12.050 \\
\hline
\end{tabular}

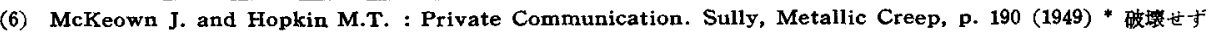

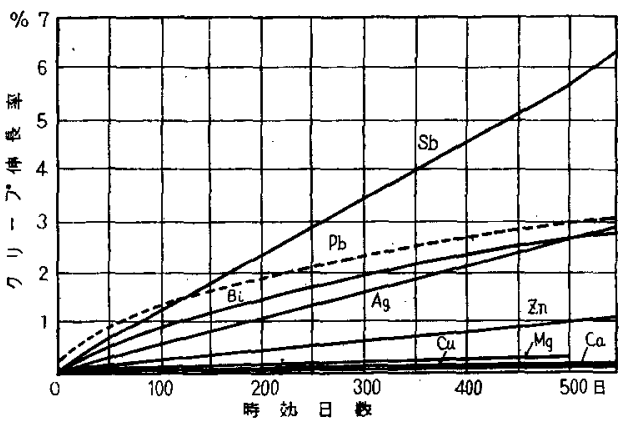

第 2 区 鉛及び各種金属添加合金のクリ一 $フ ゚$ 曲線

(Greenwood and Worner)

内外添加すれば鉛のクりープによる破堎を殆んど完全に 防止することが出来るが $\mathrm{Mg}$ は鉛の耐蝕性を悪くする のて $\mathrm{Ca}, \mathrm{Cu}$ を用いる場合加多い。

鉊の強度と耐蝕性を増すために高純度鉛に $\mathrm{Ag}, \mathrm{Ca}, \mathrm{Cu}$ の 1 種或は 2 種を $0.1 \sim 0.4 \%$ 添加して工業的使われ ているがこれらは鉊の弱点であるクリープ特性を消失さ せることが出来る．Sbを196添加した鉊は純鉛よりる 却つてクリープを增しているととが図に明らかであるが $\mathrm{Sb}$ はか十る少量を鈶に添加することはなく 3〜12\% の 範囲で添加していわゆる硬鉛にして用いる。

高純度鉊はそのま」で工業的に余り用いらるないが 塔式硫酸工場の鉛張り飞99.995\%以上の鉛を使用して耐 久年数を延長した例がある。

ドィツの或大きな製鍊所の硫酸工場では鉛張りの寿命 は極めて短かからたがこれを高純度鉛で張り替えたとこ ろ10 年を経過しても殆んど酸玲による補修の必要がな かつた.しかしこの際注意すべととは高純度鉛のクり 一プ現象による重裂乃至破壇であつて高温度 $\left(60 \sim 70^{\circ} \mathrm{C}\right)$ のしかる振動のある皆所には高純度鉛に $\mathrm{Ca}, \mathrm{Cu}, \mathrm{Sb}$ 等 の金属を加えてクリープを起させないようにした鈶を用 いなければならない，次の第 2 表は99.995\%以上の品位 を有する TADANAC 電気鈶, とれに Ag 0.005\%, Cu $0.005 \%$ を添加した B.S. 1085 合金, $\mathrm{Cu} 0.06 \%$ を含 なせた合金及び Ag 1\%を加えた4 種類の材料で造つた
ケーブル・シースのクリープテストの結果を示す.

高純度鉊のケーブル・シースは結晶組織が粗大であっ て $70 \mathrm{~kg} / \mathrm{cm}^{2}$ の荷重では約 1 日で破壊されるが, $\mathrm{Ag}$

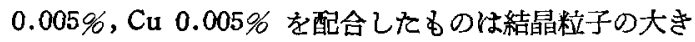
さが純鉊のときに比して約 $1 / 2$ そなるだけであるが 600 h 近くの引張り飞耐克る. Cu $0.06 \%$ のみの配合の場 合には粒子の大きさは約 $1 / 50$ 大なるが $110 \sim 120 \mathrm{~h}$ の負 荷に耐えるのみである.Ag 1\%の配合の合金では粒子の 大きさは1/100となり一躍 12,000 h 以上の荷重に耐兄 る. 前述のよ5に Sb は 196程度加元て子却つてクリ一 プ伸長を増すのみで逆效果があり，3〜12\%を添加しな ければ改良出来ない，鉛合金の機械的性質を改良するた め $\mathrm{KCa}, \mathrm{Cu}, \mathrm{Ag}$ を加調するとき鉛地金中の他の不純物の 含有量を吟味し，出来るだけ高純度の鉛を用いなければ ならないのはこの理由による。

\section{4. 鉛及び殓合金の耐鳋性}

鉊は硫酸その他に対して耐蝕性が強いのて化学工業そ の他の工場施設の耐酸材料として広く用いられている が，これは鉛が金属として酸に強いとい5のではなく例 えば鉛を硫酸に漫した時は鉛の表面に硫酸鉛の極めて薄 い層が出来てそれが酸に難溶性であるためこれが鉛地金 と酸とを㵂断し爾後の鈶の窝蝕がないのである.塩酸， 過塩素酸, 珪フツ酸, 珪酸等《鉛が窝蝕されるのは鉛が これらの酸と反応して出来た化合物が可溶性であるから 鉛は次第に窗蝕される. 次の第 3 表は鉛の化合物の水に 対する溶解度を示す.

第 3 表 鉛塩類の水に対する溶解度 (I. Müller) ${ }^{(\tau)}$

\begin{tabular}{|c|c|c|c|c|c|}
\hline 堭 & $\begin{array}{l}\text { 温度 } \\
\left({ }^{\circ} \mathrm{C}\right)\end{array}$ & $\begin{array}{c}\text { 溶解 度 } \\
(\mathrm{g} / 100 \mathrm{~g})\end{array}$ & 類 & $\begin{array}{l}\text { 温度 } \\
\left({ }^{\circ} \mathrm{C}\right)\end{array}$ & $\begin{array}{c}\text { 染解度 } \\
(\mathrm{g} / 100 \mathrm{~g})\end{array}$ \\
\hline $\mathrm{PbSO}_{4}$ & 25 & $0.42 \cdot 10^{-2}$ & $\mathrm{PbCO}_{3}$ & 20 & $0.17 \cdot 10^{-3}$ \\
\hline $\mathrm{PbCl}_{2}$ & 25 & 0.041 & $\mathrm{PbCrO}_{4}$ & 20 & $0.42 \cdot 10^{-5}$ \\
\hline $\mathbf{P b I}_{2}$ & 20 & 0.065 & $\mathrm{PbSiF}_{6}$ & 20 & 81.9 \\
\hline $\mathrm{Pb}\left(\mathrm{ClO}_{3}\right)_{2}$ & 25 & 81.5 & $\mathrm{~Pb}\left(\mathrm{C}_{2} \mathrm{H}_{3} \mathrm{O}_{2}\right)_{2}$ & 20 & 27. \\
\hline
\end{tabular}

(7) Tödt, Korrosion u. Korrosionschutz, s. 306 (1955)

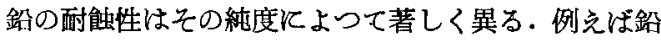
の硫酸溶液に対する酎蝕性る鉊の純度によつて差があ $\eta$, 鉛V $\mathrm{Zn}, \mathrm{Sn}, \mathrm{As}, \mathrm{Bi}, \mathrm{Sb}$ 等が含まれる時は硫酸によ つて甚だしく侵される ${ }^{(8)}$. 次の第 3 図は蓄電池硫酸溶淮 
に対する純鉛，蓄電池鉛及び Sn $1.1 \%$ を含む鉓の窝蝕 量を示す。

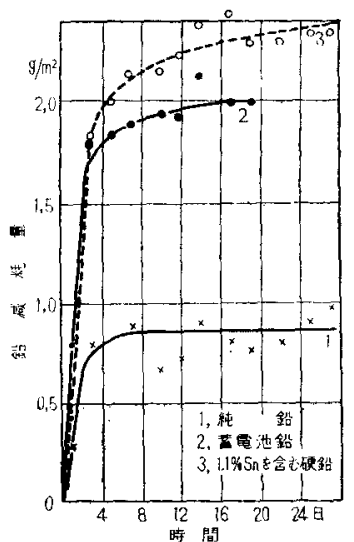

第 3 図 純鉛，蓄電池鉛及び Sn $1.1 \%$ を含 む硬鉛の消粍

蓄電池用鉛中 $\mathrm{Bi} か ゙ 0.05 \%$ 以上るとき耐蝕性が目 立つて偲くなる. $\mathrm{Ag}, \mathrm{As}, \mathrm{Co}, \mathrm{Cu}, \mathrm{Hg}, \mathrm{Ni}, \mathrm{Sn}, \mathrm{Zn}$ 等は $0.002 \sim 0.01 \%$ 以下極限しなければ鉛の耐蝕性を鱼く する(9). 乙かし䋹中K Te が0.03〜0.1\%あるときは却 つて硫酸烧対する鉛の耐強性を増す. $99.99 \%$ 鉛注 99.9 \%の8のに比して熱濃硫酸に対する耐蝕性が強い. 鉛中 の微量の $\mathrm{Cr}$ や相当量の $\mathrm{Sb}, 0.08 \%$ 程度の $\mathrm{Te}$ は鉛の 耐蝕性を助ける作用がある(9)。

塔式又怡鉛室硫酸工場に於てはとの構造材料の主なる ものが鉛板，鉛管であるがこれに用いる金属鎑は最純の るのが最も耐蝕性がよいので望ましい. 次の第4 図 ${ }^{(10)}$

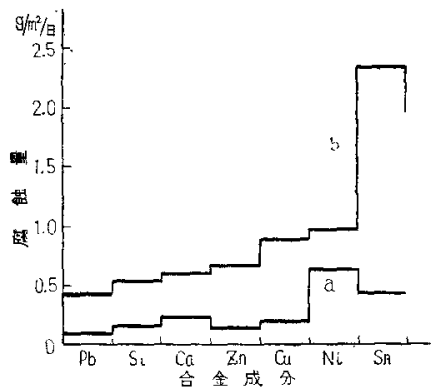

第 4 図鉛及鉛合金（各元素 $1 \%$ 添加）の $60^{\circ} B \dot{e}^{\prime}$ 硫酸仅対する腐蝕速度

(a) Nitrosyl を含まない硫酸

(b) Nitrosyl を含む碳酸

$60^{\circ} \mathrm{Be}$ の硫酸に対する鉛之各種金属を1\%ずつ含さ鉛合 金の霍強速度を示すすのて Sn 1\%を含さ鉛は Nitrosyl を合む硫酸に甚だしく侵されることを示す。

\section{3. 亜鉛の純度とその性質}

\section{1. 要鈴の精製}

亜銷は初わ蒸溜法によつて製錬されて市場に出たがこ

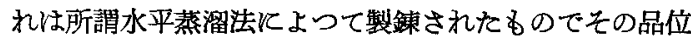

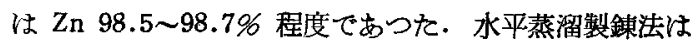
100年以上前から欧洲飞於て創められて以来今日に至る まで依然として存続され，吙の構造も操業法も殆んど变 つていないが製鍊の原料として用いられる严鉛精鉱の品 位が上昇して来たので操業成樍もそれ往つて上昇して 来た。しかし製品の品位は依然 Zn 98.7\% 内外のま」 である・このいわゆる Prime Western 級と称せられる 西鉛古くから大部分鉄板や鉄線の乾式鍍金の用供さ れて今日に至つているが最近西鉛鍍鉄板の物理的及び化 学的性䫓を改良するための研究が吹米汇於て進められ， 高純度亚鉛炕望及通りの合金成分を配合して高性能の西 鉛鍍鉄板を製造する試みる企てられ研究結果も見られる に至つた・これはまだ経済的に有利であるとは確認され てはいないが注目を要する問題である。

昔は黄銅，青銅との他の合金を製造するときるこの Prime Western 級の刺鉛が使われていたがこの亜鉛の 中の $\mathrm{Pb}, \mathrm{Cd}, \mathrm{Sb}, \mathrm{As}, \mathrm{Fe}$ 等が合金の性賈に極めて有害な 影響を与学るので今日に於てはこの用途には 99.99\%内 外の高純度西鉛を用いるようになつた。

a) 西鉛の畭式精製

New Jersey Zinc Co. (米国) は竪型蒝溜炣による連 続的巠鉛乾式製錬法を工業化して Zn 99.3\% 程度の亜鉛 を高能率で製造し，更にこれを精製炣にかけて $\mathrm{Pb}, \mathrm{Cd}$ そ の他の不純物を殆んど完全に除去して99.995\%以上の高 純度覀鉛を製造するに至つた。この方式による工場は斬 次米国のみならず欧洲にる建設せられ将来は水平蒸溜法 に取つて代るものと予想される至つた. New Jersey Zinc Co. はこの精製亚鉛でダイカスト合金を製造し， いわりる ZAMAK の商品名で発表するに至り，亜鉛多 イカスト製品の性質を大幅に改良し今日に挍ける亜鉛ダ イカスト工業の確立の基礎を作つた。

この精溜法によつて精製される亜鉛の成分は $\mathrm{Pb}<$ $0.002 \%, \mathrm{Fe}<0.0025 \%, \mathrm{Cd}<0.0015 \%$, Sn trace, Cu trace, Zn $99.994 \%$ で経済を多少犠牲にしてこの再 蒸濯を行兄ば $99.9996 \%$ の亜鉛を造ることが出来る(11).

乾式法即ち分別蒸溜法によつて精製された99.995\%級 高純度西鉛の物理的，化学的性質は次飞述べる電解法に よつて得られた同一品位のるのよりる僅かながら良好で ある・これは同一品位の亜鉛であつても不純物の種類と 量が異るためであると若觉られるが末だ確実な笑証は示 されていない。

\section{b) 亜鉛の湿式精製}

西鉛の電解精鍊の研究々遠く 1880 年頃から行われて いたがその後 30 年間は海綿状重鉛を析出する程度て工 業化が出来ないでいた．その間飞硫酸西鉻溶液中の不純 物イオンの影響が漸次明らかルなり，高純度亞鉛を平滑 に電着するためには硫酸亜鉛溶液中の不純物イオン例え 
ぼ $\mathrm{Cu}^{++}, \mathrm{Cd}^{++}, \mathrm{Fe}^{++}, \mathrm{Fe}^{+++}, \mathrm{Ni}^{++}, \mathrm{Co}^{++}, \mathrm{Cl}^{-}$等を出来 限り除去しなければならないのでこれらのイオンの除 去法が発達し，漸次技術る進歩し1917年頃《はカナダの Trail, 米国の Anaconda K工業的規模の互鉛電解工場 が湕設されるに至つた，その当時の電気西鉛の品位は 99.97\% 程度のわのであつたが当時の最高純度覀鉛とし て黄銅や特殊青銅の材料として賞用され，又亜鉛ダイカ スト合金の材料としてる利用されると至つた. $99.97 \%$ 級の亜鉛では亜鉛ダイカストトの場合にはまだ不充分で不 純物の中 $0.015 \% の \mathrm{~Pb}, 0.01 \% の \mathrm{Cd}$ が合金の機械的

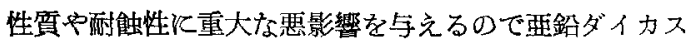
卜工業も発展を阻まれていた. 1920年に至り Tainton が Ag $1 \%$ 鉊合金陽極を用いた高酸高電流密度の電解法 を発明し Trail, Anaconda そ対抗して Kellogg そパイ ロットプラントを貄設して操業を閉始したが製品の品位 は 99.99+\% \% 槀純度飞なつたので金属加工業界飞歓迎 されるに至つた.しかし Tainton 法では 20 25\% $\mathrm{H}_{2} \mathrm{SO}_{4}$ の高酸と $1000 \mathrm{~A} / \mathrm{m}^{2}$ の高電流密度を使わればならない ので工場の設計や作業標準を維持するのが困難であつた ので1930年沃至り Siemens Halske の Georg Eger が 中酸, 中電流密度の電解法即ち折哀法を案出乙 Magdeburgに於て工業化したところ Tainton 法よりも操業が 容易でしかる $99.995 \%$ 程度以上の製品を得ると至つた。 それるでに Tainton 法によつて建設された各地の電解 . 工場もMagdeburg 工暢の成績を知るに及儿で操業条件 を変更したところも多かつた. 1940年以後に建設された 各国の亜鉛電解工場㤃㱠んぞすへて Magdeburg 法に よつている. 爾来電気亜鉛の品位は濑次上昇し，99.995 〜99.998\%の高純度正鉛が大量飞生産されるに至り, 従 つて各種合金の性能も自然に改良されるに至つた。

採算を第 2 として $99.998 \%$ の亜鉛を減圧再蒸溜すれば 99.9996\% 程度の超高純度西鉛を得るがこのよ5な亜鉛 は学術研究用又は特殊の工業用供されるのみであつて 一般用には99.995\%程度の暨鉛で允分である. 次の第 4

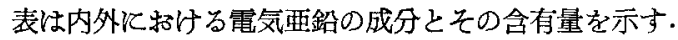

次の第 $5 \sim 9$ 図山之れぞれ水平蒸溜覀鉛, 竪型蒸溜無 鉛；一般電気亜鉛及び高純度電気西鉛の顕微鏡写真を示 す.これらの写真によれば亜鉛の純度が上昇するに伴つ て結晶内並びと結晶粒間の不純物が次第に少くなつて $99.995 \%$ 以上の品位となれば粒界にある不純物圾認めら
れない状態となることが明らかである。

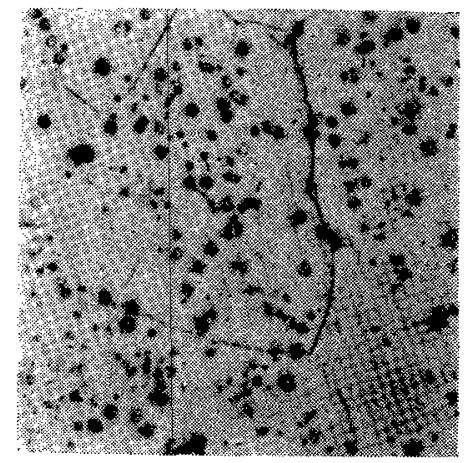

第 5 図

水平蒸溜愛鉛 $(98.85 \% \mathrm{Zn})$, 金型鋳造後 $200^{\circ} \mathrm{C}, 5 \mathrm{~h}$, 焼鈍試料の顕微鏡組織 $\left(\mathrm{CrO}_{3}+\mathrm{Na}_{2} \mathrm{SO}_{4}\right)$ エッチ $\times 400$

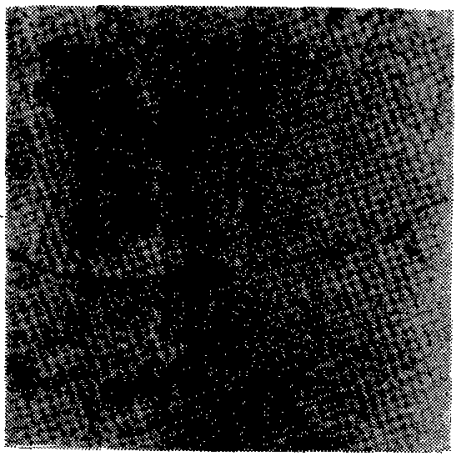

第 6 図

竪型蒸溜严鉛 $(99.7 \% \mathrm{Zn})$, 金型錆造後 $200^{\circ} \mathrm{C}, 5 \mathrm{~h}$ 焼鈍試料の顕微鏡組織 $\left(\mathrm{CrO}_{3}+\mathrm{Na}_{2} \mathrm{SO}_{4}\right)$ エッチ $\times 400$

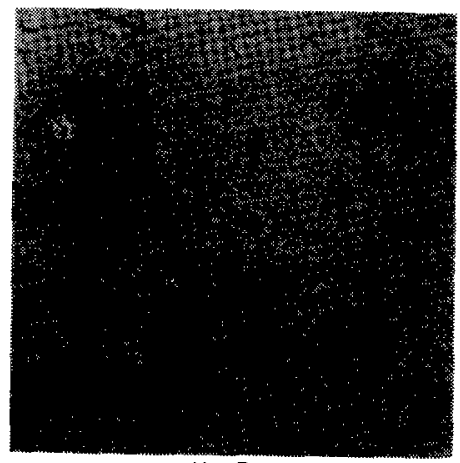

第 7 汹

一級電気要鉛 $(99.985 \% \mathrm{Zn})$, 金型鋳造後 $200^{\circ} \mathrm{C}, 5 \mathrm{~h}$ 焼鈍試料の影微鏡組織 $\left(\mathrm{CrO}_{3}+\mathrm{Na}_{2} \mathrm{SO}_{4}\right)$ エッ $\times 400$

第 4 表 電気亜鉛の成分分析表 （\%)

\begin{tabular}{|c|c|c|c|c|c|c|c|c|}
\hline 成 & 分 & 不 & $\begin{array}{c}\text { Monsanto } \\
\text { (米 国) }\end{array}$ & $\begin{array}{l}\text { Anaconda } \\
\text { (米 国) }\end{array}$ & $\begin{array}{c}\text { Trail } \\
\text { (加奈陀) }\end{array}$ & $\begin{array}{l}\text { Kellogg } \\
\text { (米 畕) }\end{array}$ & 神 & 本) \\
\hline & $\mathbf{b}$ & 0.0006 & 0.0026 & 0.007 & 0.0035 & 0.005 & & 0.0025 \\
\hline & $\mathrm{Cd}$ & 0.0001 & 0.0012 & - & - & - & & 0.001 \\
\hline & $\mathrm{Fe}$ & 0.0005 & 0.0009 & - & $\rightarrow$ & - & & 0.001 \\
\hline & $\mathrm{Cu}$ & 0.0005 & 0.0003 & - & - & - & & 0.0005 \\
\hline & $\mathrm{Zn}$ & 99.9983 & 99.9950 & 99.990 & 99.993 & 99.994 & & 19.995 \\
\hline
\end{tabular}




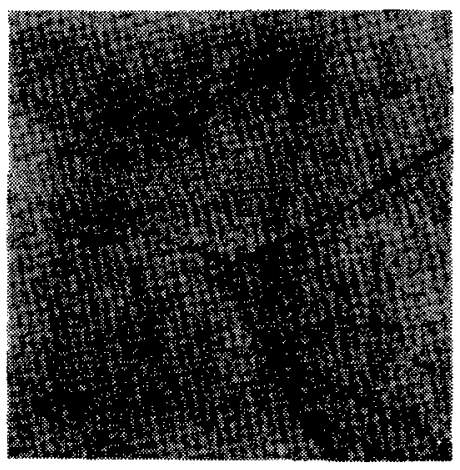

第 8 図

高純度䉓気亜鉛 $(99.995+\% \mathrm{Zn})$, 金型錆造後 $200^{\circ} \mathrm{C}$, $5 \mathrm{~h}$ 焼鈍試料の顕微鏡組織 $\left(\mathrm{CrO}_{3}+\mathrm{Na}_{2} \mathrm{SO}_{4}\right) \simeq ッ チ$ $\times 400$

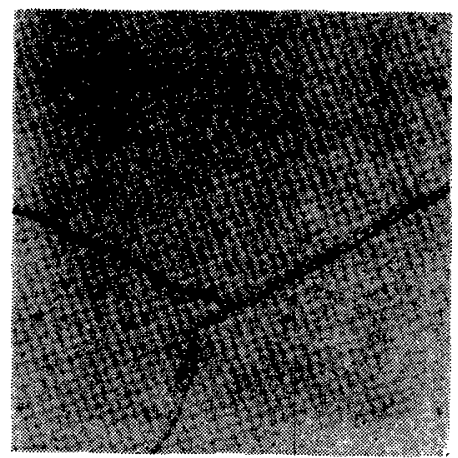

第 9 図

超高純度亜鉛 $(99.9995+\% \mathrm{Zn})$, 金型鋳造後 $200^{\circ} \mathrm{C}$, $5 \mathrm{~h}$ 焼鈍試料の顕微鏡組織 $\left(\mathrm{CrO}_{3}+\mathrm{Na}_{2} \mathrm{SO}_{4}\right) エ ツ 天$ $\times 400$

\section{2. 覀鉿の物理的性窝}

高純度西鉛の物理的性質の主なるるのを次に挙げる。

比重. 7.14

熱膨脹係数 $35.4 \times 10^{-6} \mathrm{~cm} /{ }^{\circ} \mathrm{C}\left(\mathrm{O}^{\circ} \mathrm{C}\right)$

熔融点 $419.47^{\circ} \mathrm{C}$

融解熱. $1.516 \mathrm{kcal} / \mathrm{g}$-atom

沸騰点. $906^{\circ} \mathrm{C}$

熱伝導度 $0.270 \mathrm{cal} / \mathrm{cm} / \mathrm{sec} /{ }^{\circ} \mathrm{C}\left(\mathrm{O}^{\circ} \mathrm{C}\right)$

電気伝学度 $.5 .7 \times 10^{-6} \Omega \mathrm{cm}^{-1}\left(28^{\circ} \mathrm{C}\right)$

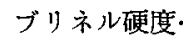
$.35 \mathrm{~kg} / \mathrm{mm}^{2}\left(20^{\circ} \mathrm{C}\right)$

抗張力. $2 \sim 7 \mathrm{~kg} / \mathrm{mm}^{2}$

伸長率. $42 \%$ (圧延板)
以上の数值で明らかなよろに高純覀鉊は機械的強度が 極めて弱く，そのま」では機械その他の構造材料に用い ることは殆んどない.しかし次に述べるように耐蝕性が 強く，粒間窝蝕が殆んどないのでれそAl, $\mathrm{Cu}, \mathrm{Mg}, \mathrm{Ni}$, $\mathrm{Cr}, \mathrm{Mn}$ その他の合金成分を添加して黄銅，特知青銅， 亜鉛ダイカスト合金, 鈑金プレス用合金等にして高性能 を出すととが出来る、亜鉛及び覀鉛合金す鉛の場合と同 様にクリープ現象を起す。第 5 表(12) は各種の亜鉊及び ダイカスト合金のクリープ試験の結果を示す.

この表に明らかであるよ 5 K $\mathrm{Al}, \mathrm{Cu}$ 等を最純亜鉛に 添加することによつて垔鉊のクリープその他による変形 及び破壊を防止することが出来るので重鉛基合金が鋳造 用上してダイカスト，鈑金プレスダィス，プラスチック スの注入ダイス等化用いられる外鐉造, 圧延, 押出しそ の他の目的に用いられ得るのである。

高維度亜鉛の再電解又は減圧低温による再㞀溜によう て出来る99.999+\%の超高純度西鉊は学術研究その他特 殊の用途々供せられる程度であつた前述の工業的用途に 使うには余りに高価であり，又その必要がない。

\section{3. 西鉛の耐触性}

一般に覀鉛は酎蝕性の弱い金属であると信ぜられて来 た. 硫酸, 塩酸等の水溶液には容易飞侵され水素を発生 し短時間の間に溶解し終るのであるが，これ゙は亜鉛がそ の中の不純物である $\mathrm{Pb}, \mathrm{Cd}, \mathrm{Fe}, \mathrm{Cu}$ 等との間に局部電池 を作り亜鉛が溶解してとれらの金属の表面に水素を析出 させるために起るので，不純物の含有量が極微量である 高純度亜鉛流酸, 塩酸等に対しても相当の耐酸性を有

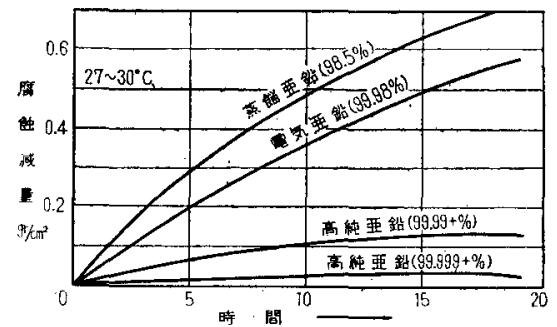

第10図 $1 \mathrm{~N} \mathrm{H}_{2} \mathrm{SO}_{4}$ 液Kよる各種互鉛の腐蝕

している.第 10 図は各種の亜鉛を 1 -N 硫酸に浸清し た場合の腐強隇量を示したるのである. 㙁酸による溶解 の場合子略同様な結果を得る。又 $99.9 \%$ 程の電気亜鉛 を小片に錆造し1：4 亿薄めた确酸溶液に溶解するのに $30 \min$ かっるが $99.99+\%$ の純度になれば 2 ケ月以上

第 5 表 各種亚鉛及びその合金のクリープ試験結果 (Messner)

\begin{tabular}{|c|c|c|c|c|c|c|c|c|c|c|c|}
\hline \multirow{2}{*}{\multicolumn{2}{|c|}{ 試 }} & \multirow{2}{*}{ 料 } & \multicolumn{3}{|c|}{ 成 } & \multicolumn{2}{|c|}{ 分 $(\%)$} & \multirow[b]{2}{*}{$\mathbf{M g}$} & \multicolumn{3}{|c|}{ 10,000 h で次の歪を起させる施力 } \\
\hline & & & $\mathrm{Cu}$ & $\mathrm{Al}$ & $\mathrm{Pb}$ & $\mathrm{Fe}$ & $\mathrm{Cd}$ & & $1 \%$ & $0.5 \%$ & $0.2 \%$ \\
\hline 電 & 気 亜 & 䟻 & - & - & 0.005 & $<0.005$ & $<0.005$ & - & $<1 \mathrm{~kg} / \mathrm{mm}^{2}$ & $<1 \mathrm{~kg} / \mathrm{mm}^{2}$ & $<1 \mathrm{~kg} / \mathrm{mm}^{2}$ \\
\hline 重 & 鉛 & 板 & $<0.01$ & - & 0.71 & 0.023 & 0.06 & - & $<1$ & $<1$ & $<1$ \\
\hline \multicolumn{3}{|c|}{$\begin{array}{l}\mathrm{Zn-4} A \mathrm{Al}-1 \mathrm{Cu} \\
\text { (押出L後焼鈍) }\end{array}$} & 0.77 & 4.11 & 0.005 & $<0.02$ & $<0.005$ & 0.015 & 5.59 & $3 . \dot{78}$ & 1.10 \\
\hline
\end{tabular}


る必要とすることでも重鉊の密蝕の大部分が不純物によ る電気化学的窝蝕であることが判る.

亜鉛中の不純物の微量は亜鉛と固溶態を形成するが $\mathrm{Pb}, \mathrm{Cd}, \mathrm{Sn}$ 等の大部分は多元の低融温度の共晶, 或は金 属間化合物を作つて覀鉛結晶粒間に入る.局部電池は主 として亜鉛結晶とその周辺の $\mathrm{Pb}, \mathrm{Cd}, \mathrm{Sn}$ 等の多い粒間 介在物の間に形造せられ覀鉛の溶解が起る。この現象が 続行すれば重鉛文はとの合金はその結晶粒間に沿つて急 速に溶解し，いわ方粒間窝蝕を起す. $99.98 \%$ 程度以 下の電気垔鉛で製造したダイカスト合金が鍀造後空気中 の水分, 雨水或は海水などによつて粒間窝蝕を受けて異 状膨張をしたりするが99.995\%程度以上の電気覀鉛を原 料とすれば この障害を完全に防ぐことが出来る. 亜嵞 ダイカスト合金中の規格飞 $\mathrm{Pb}$ は 0.003 0.004\%以下， Cd $0.002 \%$ 以下, Sn 0.002 以下と規定してある のはこの理由による。

\section{4. 結語}

高純度鉛及び高純度覀鉛の製造法, その純度，不純物 の種類及び物理的, 化学的性質についての概要を以上の 如く述べたが，か〉る高純度金属はそのま〉では学術的 研究が特智の目的行用いられるのみで広い需要面から大 量に求められるととはない。しかし前に述へた通り銛， 亜鉛を主成分とした各種各樣の合金壮その用途が極めて 広く，その需要量子毎年増加する傾向にある。これらの 合金の物理的,化学的性筫が各国で研究されているが鉛, 亜鉛の中の不純物が合金の性質に重大な影響を及ぼし， 不純物の種類によつてはその含有量が $1 / 100,000$ 違つて 6合金の強度や耐強性に著しい差異を生せしめることが
明らかてなり，合金製造者は出来る限り糺度の高い銛， 亜鉛を要求するようになつた。このととは鉛，西鉛に限 らず他の金属に於ても全く同じである。この理由により 製鍊業者はとの製品である各種金属の純度を競らように なり，作業管理，品筫管理に意を用いている．即ち如何 として最高純度の金属を低廉なコストで製造するかを常 そ研究している.

金属の純度が上昇するて伴い各種合金の生能が良くな り，更飞新しい用途を見出してその金属の応用面を拡允 てているのが業界の現状であるから高純度の製造法及び その性質の研究は世界の工業の発展のためと最も肝要な 科学技術の研究の一つであると信ずる.

\section{文献}

(1) Mantel1 : Industrial Electrochem., 314 (1950)

(2) 西村敏栍：日本鉱莱会誌， 66, 1(1950)

(3) 同 上: " 66, 61 (1950)

(4) Mantell : Industrial Electrochem., 322 (1950)

(5) J.N. Greenwood, H.K. Worner: J. Inst. Met., 64, 144 (1939); Sully : Metallic Creep., 141 (1949)

(6) J. Mc Keown, T.M.T. Hopkin: Private Communication; Sully: Metallic Creep, 190 (1949)

(7) Tödt: Korrosion u. Korrosionschutz s. 306 (1955)

(8) Katz: Korrosion des Bleis. Auflosung in zeitlichen Abhängigkeit. Metalloberfl., 7 s. 161 (1953)

(9) O.W. Groscheim-Krisko, H. Hanemann, W. Hofmann : Z. Metallkde., 34, 97(1942); H. Buckel, H. Hanemann: Beitrag aum Studium der anodischen Korrosion im Bleisammler, Z. Metallkde, 32, 120 (1940)

(10) K. Wickert: Korrosionserscheinungen an Bleilegierungen. Korroston. u. Metallsch., 18. 357(1942);Bleikorrosion in Schwefelsäurebetrieben, Korrosion u. Metallsch., 20. 145 (1944)

(11) Gerlach W.E. Riedel: Metallwirtsch, 12, 401 (1933)

(12) Messner, O.H.C.: Ueber die Dauerbeständigkeit von Zinklegierungen, 1947 ; Sully : Metallic Creep, 193 (1949)

\section{クラッド式鉙蓄電池}

中 村 良治

(鉄道技術研 究所)

\section{1. クラッド式陽極板のはじまり}

クラッド式鉛蓄電池とは最近我国で実用化され始めた クラッド式陽極板を用いた新しい形式の鉛蓄電池のこと をいう・この「クラッド式陽極板」というのは, エボナ イトクラッド式陽極板の「エボナイト」管の代り㳊「ガ ラスファイバー」管或は「微孔合成樹脂」管などを用い たあらゆる種類の隄極板を指するのと仮に定義する。構 造的にみて従来のエボナイトクラッド式陽極板もクラッ ド式陽極板の1種とみなす方が罗当であり，密閣形スエ 置蓄電池の JISでるとの方針が採られている．しかし以 下に述へょうとするところには目下普及しつつあるいわ
ゆるクラッド式蓄電池と従来のエボナイトクラッド式蓄 電池との比較をる加えたいので，便宜上うえのよ5に定 義することとした。

エボナイトクラッド式陽極板は相当飞古い歴史を ち、これを用いた蓄電池は寿命が長いとされていた。し かし，その使用実䋶は一七とに価格の点を考えると

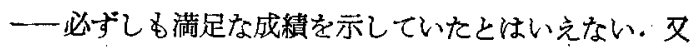
生能の面だけ限つて比較してす耐震ペース卜式蓄電池 より総ての点で勝つているとは認められない。

エボナイトクラッド式陽極板を改良しようとする試み はかなり古くからある。我国の例でいらと昭和 6 年飞横 須賀海軍工廠で武作されだボナイト製微孔隔離板と同 